\title{
Concurrent mining and reclamation for underground coal mining subsidence impacts in China
}

\author{
Yoginder P. Chugh ${ }^{1,2}$
}

Received: 8 July 2017/Revised: 20 November 2017/Accepted: 3 January 2018/Published online: 27 March 2018

(C) The Author(s) 2018

\begin{abstract}
Large scale underground mining of coal resources in China using longwall mining has resulted in ecological and environment problems, including surface subsidence that is considered serious due to competing interests of prime agricultural lands, food security, and regional economic development. The subsided lands must be rehabilitated soon after mining to be agriculturally productive to minimize loss of farmland. Similarly, precious water resources must also be managed during and after mining to protect this natural resource. Toward these goals, the concept of "Concurrent mining and subsidence reclamation (CMR)" was proposed by Professor Hu of the China University of Mining and Technology, Beijing (CUMTB). Over the last two decades CMR concepts have evolved and successfully applied in the field in different parts of China. This innovative technology has increased available farmland during the mining process, and provided better land protection and food security in mining areas even with high groundwater table. The technology has been used in 5 of the 14 large coal bases in China. This paper describes the technology concepts, design and guiding principles for planning with two case studies from different regions to enhance its application both in China and in other countries.
\end{abstract}

Keywords Mining subsidence $\cdot$ Farmland and water resources protection $\cdot$ Concurrent mining and subsidence reclamation planning

\section{Background}

China is currently the largest producer and consumer of coal in the world. According to the BP Statistics (2015), China produced about 3.75 billion $\mathrm{mt}$ of coal that is about $47.7 \%$ of the global coal production. It consumed about 3.94 billion $\mathrm{mt}$ of coal, or about $50 \%$ of the total consumption in the world. Coal mining can result in land, water, and air impacts related to waste disposal, toxic gas emissions, and land subsidence with associated changes in surface topography, and damage to land and structures ( $\mathrm{Hu}$ et al. 2016a). Land subsidence has created major ecological

Yoginder P. Chugh

siu681@siu.edu

National Academy of Inventors, Tampa, FL, USA

2 Southern Illinois University Carbondale, Carbondale, IL 62901, USA problems in China because $90 \%$ of the coal is mined from underground mining using high extraction longwall mining systems, in contrast to several other large producers of coal around the globe (USA, India, and Australia) who produce a significant amount of their coal production using surface mining methods (BP Statistics). Land subsidence impacts in China are more prominent in the east and northeast China (Hu and Luo 2006; Hu et al. 2006), which are the main coal and agricultural production regions (called "Overlap Regions") These regions cover about $40 \%$ of the total farmland in China, produce about $45 \%$ of the national food production, and mine about $58 \%$ of the national coal production. Furthermore, ground water table is relatively high in many areas of the Overlap Regions, which result in large scale water-logged agricultural areas after mining. The farmland and water resources can be highly impacted by underground mining. Therefore, technologies must be developed with the goals to: (1) make subsided lands agriculturally productive soon after mining to minimize 
loss of farmland and their pre-mining productivity level; and (2) manage water resources and regional economic development during and after mining to sustain regional economies. Toward the above goals, China's land reclamation science and technology practices has made considerable progress since the mid 1980's to restore subsided and subsiding lands to minimize impacts to natural resources $(\mathrm{Hu}$ 1994a, b). Some of the outstanding technology developments and applications until early 1990s are summarized below (Hu and Xiao 2013a, b).

(1) "Digging Deep to Fill Shallow" This technology divides the subsidence-prone areas into two parts: deep and shallow. The deep areas are dug deeper to develop fish ponds, or water recreational areas and the excavated soil is used to fill the shallow areas to reclaim lands for agriculture. Hydraulic dredging and pumping equipment are often used for this.

(2) "Direct Rehabilitation" If the shallow subsidence areas are not water-logged and the ground-water level (GWL) is also not very high, direct rehabilitation of subsided land may be possible through regrading with or without terracing to support drainage and minimize soil erosion.

(3) "Backfilling low lying areas-not currently being used for agriculture-for rehabilitation as agricultural land" It involves landfilling low lying areas with coal wastes, construction materials, and fly ash to develop agriculturally productive lands.

(4) "Subsurface Water Drainage" This technology establishes a system of drains below the subsurface water level/s to drain the impounded water and lower the subsurface water level so that the subsided land can be cultivated for agricultural production.

Reclamation methods with and without backfilling have been extensively practiced in China. However, most rehabilitation is generally done after subsiding lands have achieved the final subsidence basin or final settlement condition after mining. However, with all these approaches over $50 \%$ of the agricultural land may be already submerged into water, including some with highly fertile topsoil. Furthermore, subsiding lands are not agriculturally productive. These approaches are post-mining land rehabilitation technologies that typically result in a low percentage of farmland reclamation and high reclamation cost. Furthermore, these approaches may not allow efficient protection of water resources.

\section{Statement of the problem}

China mines coal resources in several regions (Shandong, Anhui, Henan, Hebei, and Jiangsu Province) where mining, agricultural, water resources, and regional economic development have competing economic interests. The technology developments in Sect. 1 above can now be extended to develop mining and reclamation technologies that would: (1) minimize the topographic changes related impacts of subsidence on agricultural production and productivity, and water resources quality and quantity; and, (2) synergize the different industries operations in a manner that loss of revenues from different industries are minimized during and after resources extraction. The goal is to maximize the revenue for all industries involved during and subsequent to mining of coal resources.

Currently, subsided areas after mining are generally reclaimed upon completion of mining over a large region to take advantage of the economies of scale and mining sequence for different longwall panels. This is termed here as traditional reclamation or TR or "end of pipe solution" where land grading, soil placement, and agricultural production are performed mostly after the land has stabilized (Hu et al. 2013; Hu and Xiao 2013b) after mining. TR approaches may satisfy only the first reclamation goal identified above, but they would most likely not satisfy the second goal. TR approaches may not develop efficient development and utilization of the coal, farmland and water resources, and regional economic development. Over the last $10-15$ years, researchers at CUMTB are developing alternate CMR approaches to reclaim subsided land as mining progresses. They are similar to concurrent mining and reclamation concepts used in surface mining but are more complex. Examples include research by $\mathrm{Li}$ et al. (1999) who designed a pre-reclamation plan for Liuqiao coal mine based on land damage analysis. They concluded that the best time for pre-reclamation is after skipping mining of the No. 6 coal seam and before mining the central isolated working face. Furthermore, the layout of the pre-constructed water pond must correspond with the underground mining layout. Zhao and $\mathrm{Hu}$ (2008) developed an "appropriate reclamation timing model" for subsiding land that incorporates planning for reclamation. $\mathrm{Hu}$ et al. (2013) proposed CMR concepts for longwall mining to reclaim high value land resources ( $\mathrm{Hu}$ and $\mathrm{Chen} 2016$ ), which were successfully demonstrated in the field in Anhui Province, China. In laying out mining plans, subsidence development during various stages were analyzed and pertinent factors such as vertical subsidence, post-mining slope, water area, and land use condition were considered in reclamation planning. Hu et al. (2016b) discussed a CMR design case study that considered the value of both 
land and water resources. Limited CMR research to date has focused primarily on reclamation goal 1 above and there is room for additional development even there to better protect farmland and water resources. Over the last 5 years, the Institute of Land Reclamation and Ecological Restoration at the CUMTB and Southern Illinois University Carbondale (SIUC in USA) researchers are working collaboratively. They have sought to minimize the impacts to farmland and water resources and in some cases, enhance utilization of all resources while simultaneously minimizing negative economic impacts. The goals of these development efforts are to minimize loss of and/or to enhance: (1) farmland use for agriculture during and after the entire mining process, (2) surface and ground water resources for agriculture, and economic development; and (3) revenue from utilization of all resources.

\section{Characteristics of mining regions in China}

Coal resources distribution and subsidence related surface damage characteristics. Proven coal reserves are estimated as 1.53 trillion $\mathrm{mt}$ as of 2015 and rank third in the world (Xiao et al. 2014a, b). Their distribution is shown in Fig. 1. The degree of subsidence-related damage in different mining regions varies due to the geological and hydrogeological differences. In eastern China, where ground water table is near surface, subsidence results in large lakes and wetlands impacting about $85 \%$ of the premining farmland land use. In western China, an ecologically fragile area susceptible to soils erosion, subsidence leads to increased soil erosion, depletion of water resources, lowering of ground water table, reduction in vegetation area, and land desertification. In southern China, with warm and humid climate area and hilly terrain, subsidence may cause landslides and endanger public safety. Therefore, CMR land reclamation strategies should consider regional or even site specific differences.

\section{Concurrent mining and reclamation (CMR) concepts to minimize subsidence impacts}

\subsection{Critical scientific planning elements of CMR}

Figure 2 shows the proposed four scientific design elements for CMR planning. An excellent application of the above elements with a case study was provided in Hu et al. (2016a, b). This paper presents an additional case study and summarizes the previous one to illustrate them.

(1) Identify mining area influence on the surface and subsurface

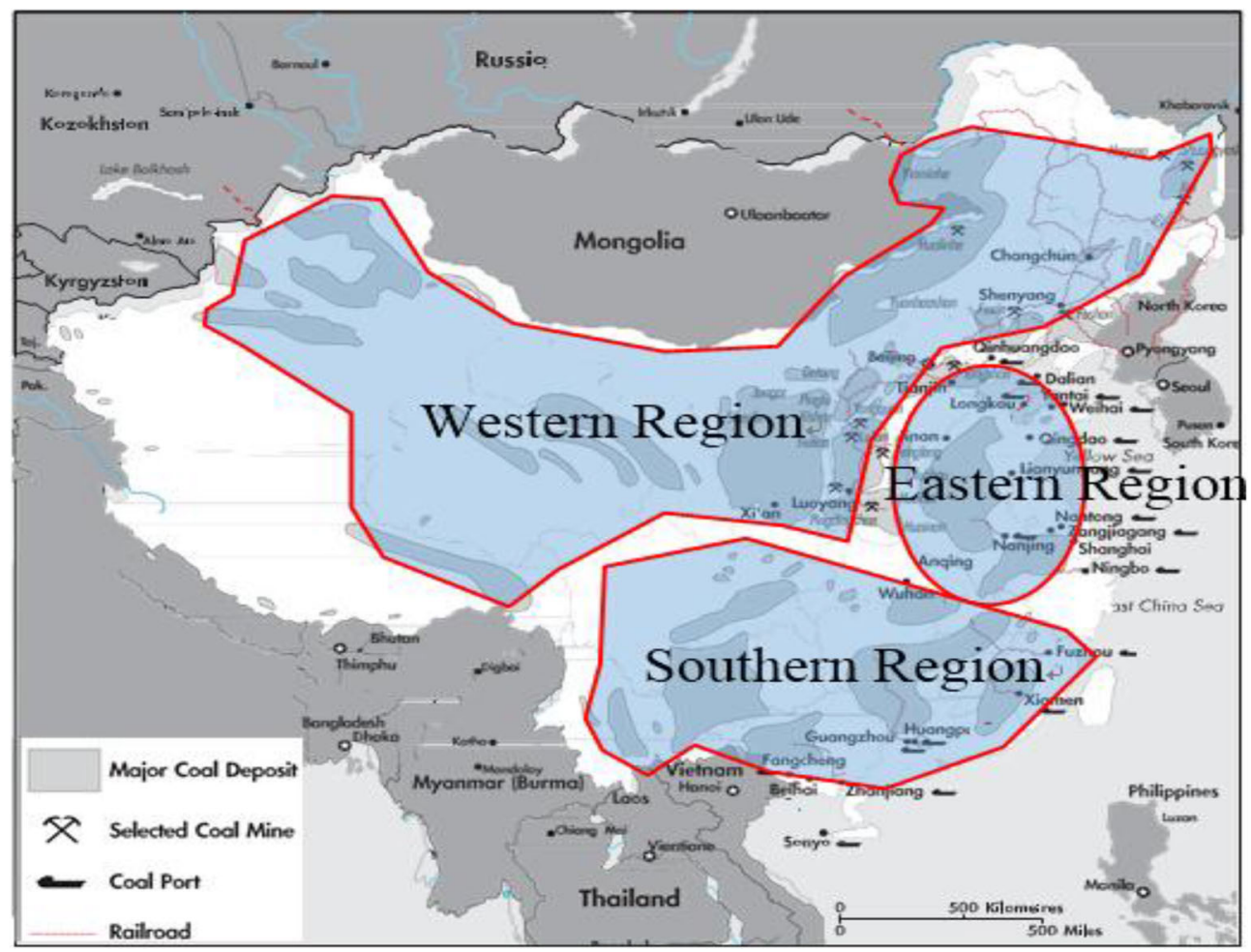

Fig. 1 Coal distribution and land reclamation regional boundaries in China. Source: modified from US DOE. EIA. Country Energy Profile. China. February 1995 


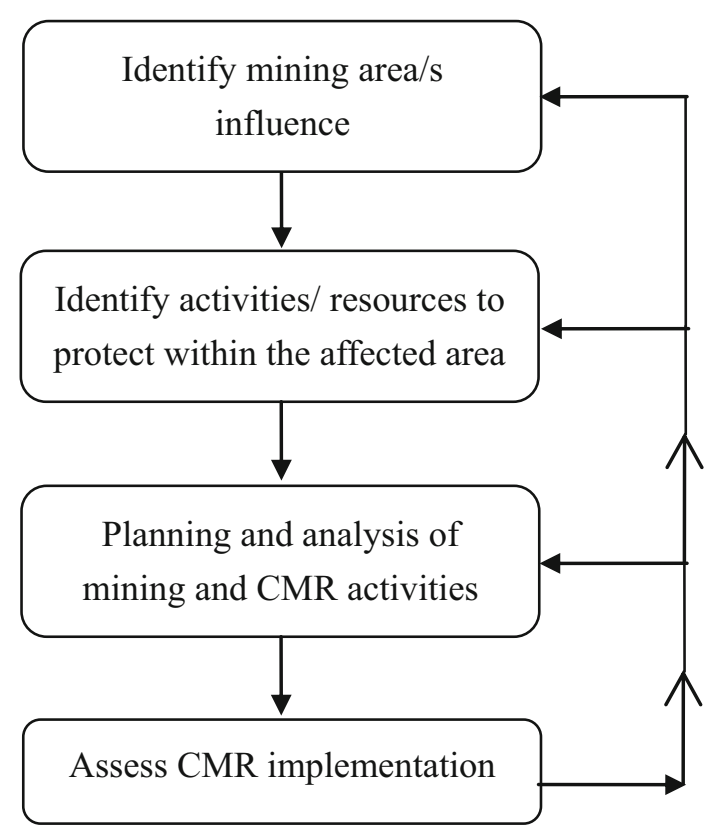

Fig. 2 Critical scientific planning elements of CMR

For a selected mining plan, this element estimates the affected area on the surface and/or subsurface due to mining over a select period of time. It utilizes characteristics of the coal seam/s and associated underlying and overlying strata (geologic, hydro-geologic, and geometric such as seam pitch, anomalies), mining operations (panel width, panel length, mining rate, etc.), regional subsidence characteristics (angle of draw, angle of break, tensile and compressive strain, etc.), and surface topography to achieve this. The goal is to identify the nature and extent of the expected influence and/or damage to the variable/s of interest (farmland, aquifer, forest land, overlying or underlying coal seam, etc.) over the area so that CMR activities can be planned to minimize the impacts within the affected area and adjoining areas as mining progresses. This design element requires good data on all of the relevant characteristics listed above. A knowledge of subsidence engineering is essential for this exercise and good software programs are available to perform the design activities.

(2) Identify activities and/or resources for protection within the affected areas

This element identifies resources (farmland, water resources, forests, structures) that need to be protected. For example, we may have to harvest the crops from the affected area before it goes under water due to surface subsidence, or we may have to remove structures, or move inhabitants away from the affected areas, or remove subsoil or topsoil from the affected areas. This element may also help identify areas where topsoil and/or subsoil may be stored temporarily to minimize CMR cost. This design element is a pre-requisite to planning CMR activities.

(3) Planning and analysis of mining and CMR activities within the identified areas

This element uses output of elements (1) and (2) above to plan CMR activities that would help protect desired resources, minimize CMR cost, and/or maximize the objective function which may be revenue from reclaimed areas through conservation and protection of identified resources, and regional and community development activities. This may require pursuing design elements (1) and (2) iteratively to achieve the desired objective function. It may consider an alternative mining plan, alternate reclamation technology or an alternate regional or community development plan. Since the near-term impact of CMR activities can be small, it is necessary to perform engineering economic analyses over an extended period of time (10 years or more) to provide a realistic view of the benefits.

(4) Assess CMR implementation on identified objectives

This analysis element provides feedback at appropriate intervals on the performance of planned CMR activities and need for alternative planning, if needed. Just like design element 3 above, this element may also require iterative analysis of alternate mining plans, alternate reclamation approaches, and regional and community development activities.

\section{CMR planning considerations}

In achieving CMR planning goals (1) and (2) identified earlier in the statement of the problem section, one must consider current or pre-mining land and water utilization and future (post-mining) or proposed land and water resources utilization potential from regional economic development point of view. The CMR planning exercise should look at multiple alternatives that would enhance the regional economic development with sustainable future. For example, CMR may consider development of larger agricultural area, a new township or a new recreational area based on expected changes in surface topography and associated damage to existing structures. CMR planning must also consider alternate, creative regional economic development opportunities to support sustainable communities and to maximize explicit and implicit revenues. Mining companies should cooperatively work with local, regional, and national community planning groups to maximize return on land rehabilitation and water resources utilization opportunities. 
CMR planning requires consideration of several important geographic, geologic, and current land use and hydrologic variables such as: (1) surface topography and spatial distribution of land slope overlying proposed mining areas, (2) geologic characteristics of soils and weak overburden overlying the bedrock; (3) agricultural productivity characteristics of soils and their variation with depth below surface; (4) surface and subsurface structures that may require subsidence damage consideration (highways, aquifers, existing reservoirs and major drainage patterns), and their future reconstruction costs; and (5) premining land and water use patterns.

The future potential for alternate uses is affected by important mining related variables that include: (1) seam thickness, seam pitch, seam pitch orientation and their variation, (2) areal extent and shape of the mining property, (3) overall size of the reserve and expected subsidenceinfluence area, (4) mining depth, (5) panel size, (6) mining advance rate, (7) multiple coal seams, and (8) mining width to depth ratio. Any surface or mining-related variables that directly or indirectly affect surface deformations must be considered. There is generally very little control on most of these variables. However, there may be some flexibility in panel orientation, panel width to depth ratio, and mining advance rate to control surface deformations and optimize CMR planning. Similarly, the presence of pre-existing water storage areas and water drainage patterns may allow some flexibility in CMR planning.

The pre-mining land use patterns vary locally and regionally, and future regional development needs (farmland, water resources, residential and commercial development needs, etc.) for economic development should be considered during the mine life of 20-30 years and could have significant impact on CMR planning. Another intuitive important factor would be the local costs for different types of reclamation (farmland, water storage and fisheries, recreation, pasture land, etc.) to achieve desired postmining land use and water management structures and facilities. The goal of CMR planning should be to look at multiple alternatives that would enhance subsidence affected areas for the regional economic development with sustainable future.

\section{Field demonstration of CMR planning through case studies in China}

\subsection{Case study I (Anhui Province, years 2007-2015)}

\subsubsection{Description of the case study area}

The study area is located in east China (Fig. 3), and is in the alluvial plain of the Huaihe River. The terrain is almost flat with ground slopes not exceeding $5^{\circ}$, with many ponds and rivers in the area. The surface elevations vary from +21.6 to $+25.4 \mathrm{~m}$ above the mean sea level or MSL (Fig. 3), with the average of $+23.1 \mathrm{~m}$. It is located in the semi-humid warm temperate continental climate with four seasons. Most rain falls in summer (from June to August) with the average value of $926 \mathrm{~mm}$. The GWL is about $1.5 \mathrm{~m}$ below the ground surface. The mine began production at the end of 2007 and extracted mainly No. 11-2 and 13-1 seams.

Pre-mining land use is a very high-yield farmland area and covers about $86.79 \%$ of the entire mining area (Fig. 4). It is a typical rice cultivation area in China with planting season from October to June. Corn is another important crop that usually grows from early June to late September. The farmland and water resources need to be protected in the area.

\subsubsection{Geology and mining plan}

There are eight (8) longwall panels (Fig. 5) in the area with the mining sequence of P1-P2-P3-P4-P5-P6-P7-P8. Among them, six (6) panels mine 11-2 coal seam and the left two (2) panels mine 13-1 seam. The average thickness of 11-2 and 13-1 seam are 2.49 and $3.56 \mathrm{~m}$. The average face advance rate is about $5 \mathrm{~m}$ per day for both faces. So it requires about 12-months to mine each panel and the case study covers about eight (8) years of mining. The near surface alluvial materials vary from 346 to $563 \mathrm{~m}$ in thickness. The relevant subsidence prediction parameters are given in Table 1.

\subsubsection{Mining impacts simulation and analysis}

The entire mining was divided into eight (8) stages based on the mining layouts: Stage 1 -completion of face P1; Stage 2-completion of faces P1 and P2; Stage 3-completion of faces P1, P2 and P3; Stage 4-completion of faces P1, P2, P3 and P4; Stage 5-completion of faces P1, P2, P3, P4 and P5; Stage 6-completion of faces P1, P2, P3, P4, P5 and P6; Stage 7-completion of faces P1, P2, P3, P4, P5, P6 and P7; and Stage 8-completion of faces P1, P2, P3, P4 P5, P6, P7 and P8. Surface displacements for each mining stage were predicted using the probability integration and Knothe time function method (Xiao et al. 2013). The subsidence-influenced region and maximum subsidence in different mining stages are shown in Table 2 and Fig. 6. Incremental surface subsidence after each mining stage with a consideration of original surface topography is shown in Fig. 7. 


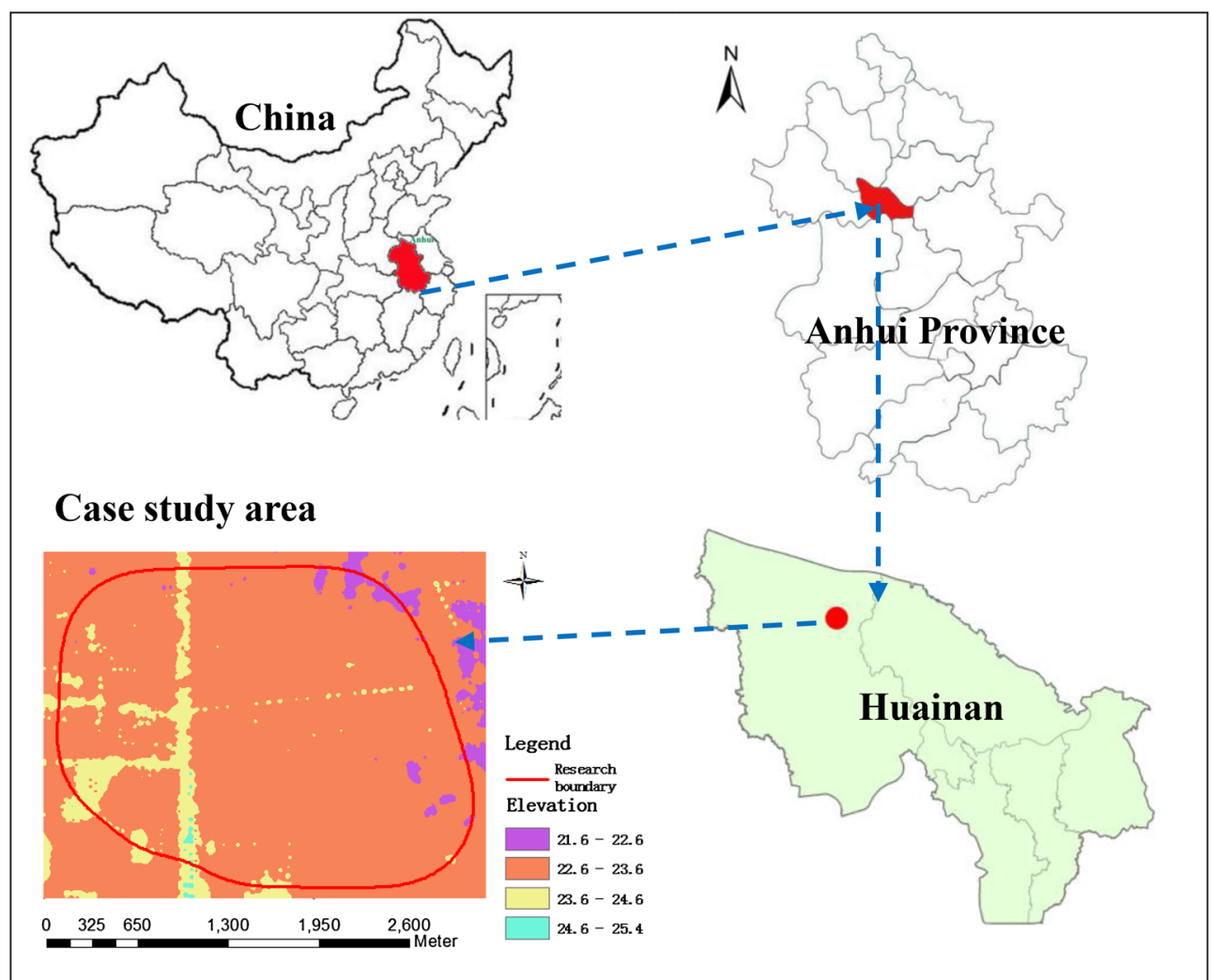

Fig. 3 Location and pre-mining surface topography of-Case study I

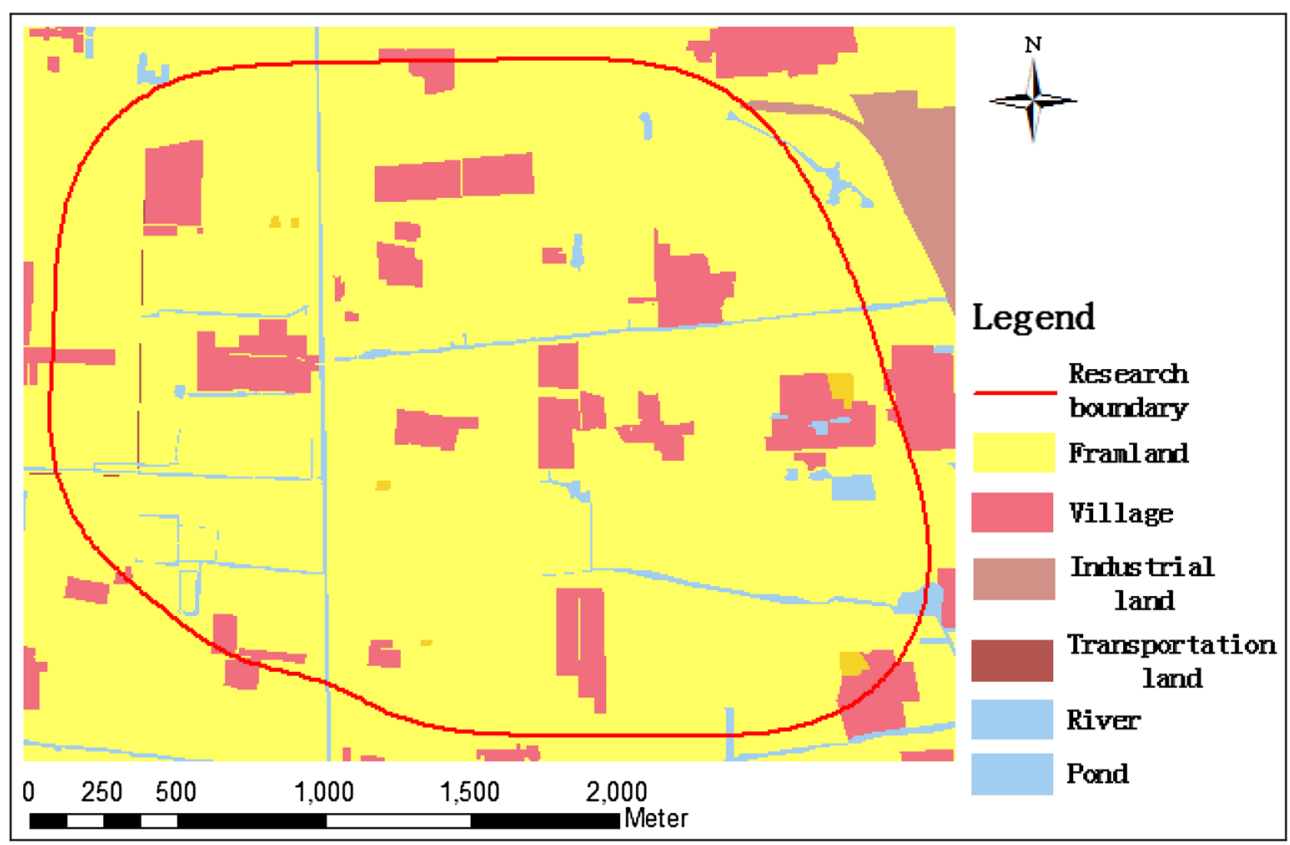

Fig. 4 Pre-mining land use distribution in the case study area-Case study I

\subsubsection{Farmland protection planning}

Analyses indicated that if the resulting surface elevation after mining subsidence was less than $+21.6 \mathrm{~m}$, the land would submerge under water and it could not be used as farmland (Fig. 8). The post-mining land use after each mining stage is discussed below. 


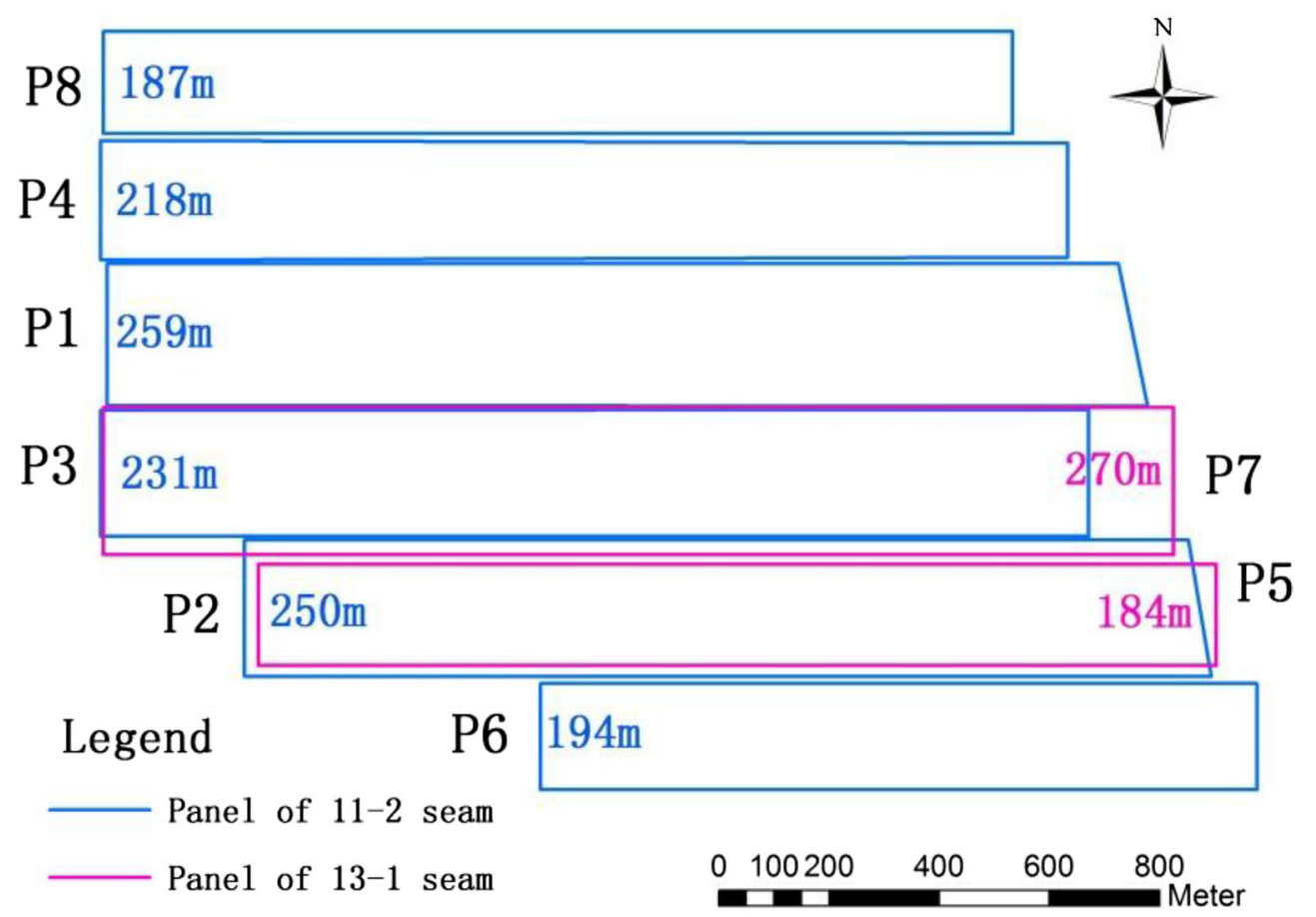

Fig. 5 Layout of longwall panels in the case study area—Case study I

Table 1 Relevant subsidence prediction parameters for Case study I and II

\begin{tabular}{lll}
\hline Parameters & Case study I & Case study II \\
\hline Subsidence factor for initial mining & 1.11 & 0.8 \\
Subsidence factor for repeated mining & 0.91 & NA/ \\
Tangent of main influence angle & 2.1 & 1.8 \\
Horizontal displacement factor & 0.31 & 0.35 \\
The displacement distance & $50 \mathrm{~m}$ & $0.07 H^{\mathrm{a}}$ \\
Influence propagation angle (deg.) & 87.6 & 87 \\
\hline
\end{tabular}

${ }^{\mathrm{a}} H$ is the mining depth

Table 2 Mining influence, water-logged and farmland areas in each stage-Case study I

\begin{tabular}{lllcc}
\hline Stage & $\begin{array}{l}\text { Max subsidence } \\
(\mathrm{mm})\end{array}$ & $\begin{array}{l}\text { Influenced } \\
\text { area (ha) }\end{array}$ & $\begin{array}{l}\text { Water area } \\
\text { (ha) }\end{array}$ & \multicolumn{1}{l}{$\begin{array}{l}\text { Water area } \\
(\%)\end{array}$} \\
\hline 1 & 1105 & 290.58 & 0.00 & 0.00 \\
2 & 1150 & 418.12 & 0.00 & 0.00 \\
3 & 2239 & 426.67 & 90.27 & 21.16 \\
4 & 2301 & 479.46 & 125.49 & 26.17 \\
5 & 3302 & 486.23 & 163.62 & 33.65 \\
6 & 3698 & 527.21 & 183.79 & 34.86 \\
7 & 5779 & 531.24 & 209.36 & 39.41 \\
8 & 5779 & 576.46 & 242.49 & 42.07 \\
\hline
\end{tabular}

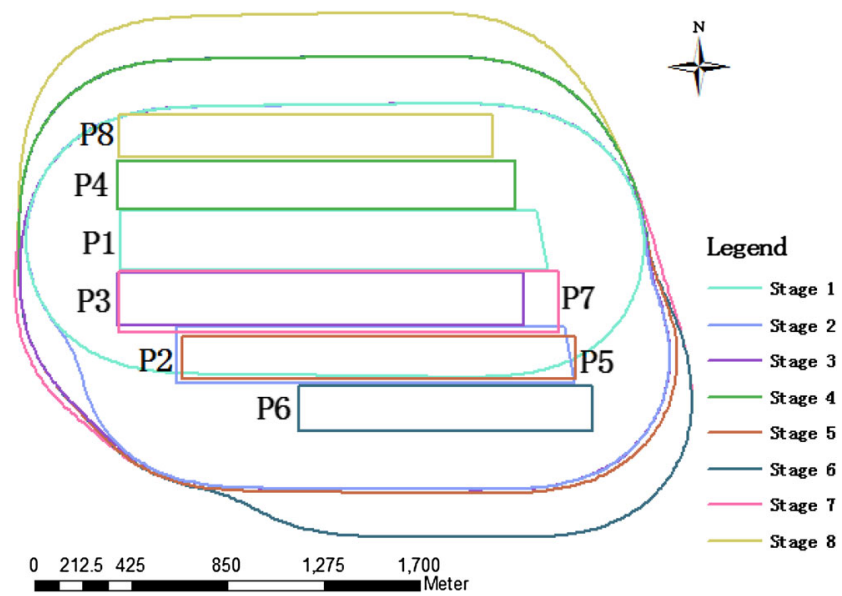

Fig. 6 Subsidence-influenced boundaries after each mining stageCase study I

Stage 1: During this stage the mining influence area is not very large, and there is no farmland that submerges into water; Stage 2: Since P2 is not adjacent to P1, the subsidence-influenced region extends over a wide area, but there are still no water-logged areas and farmland use is not impacted; Stage 3: Since P3 is located between P1 and P2, subsidence-influenced-region does not change much. However, the maximum subsidence increases to $2239 \mathrm{~mm}$ from $1150 \mathrm{~mm}$ in Stage 2 and some farmland submerges under water; Stage 4: P4 is next to P1 and subsidenceinfluenced region and water-logged areas extend towards north and more farmland submerges under water; Stage 5: 


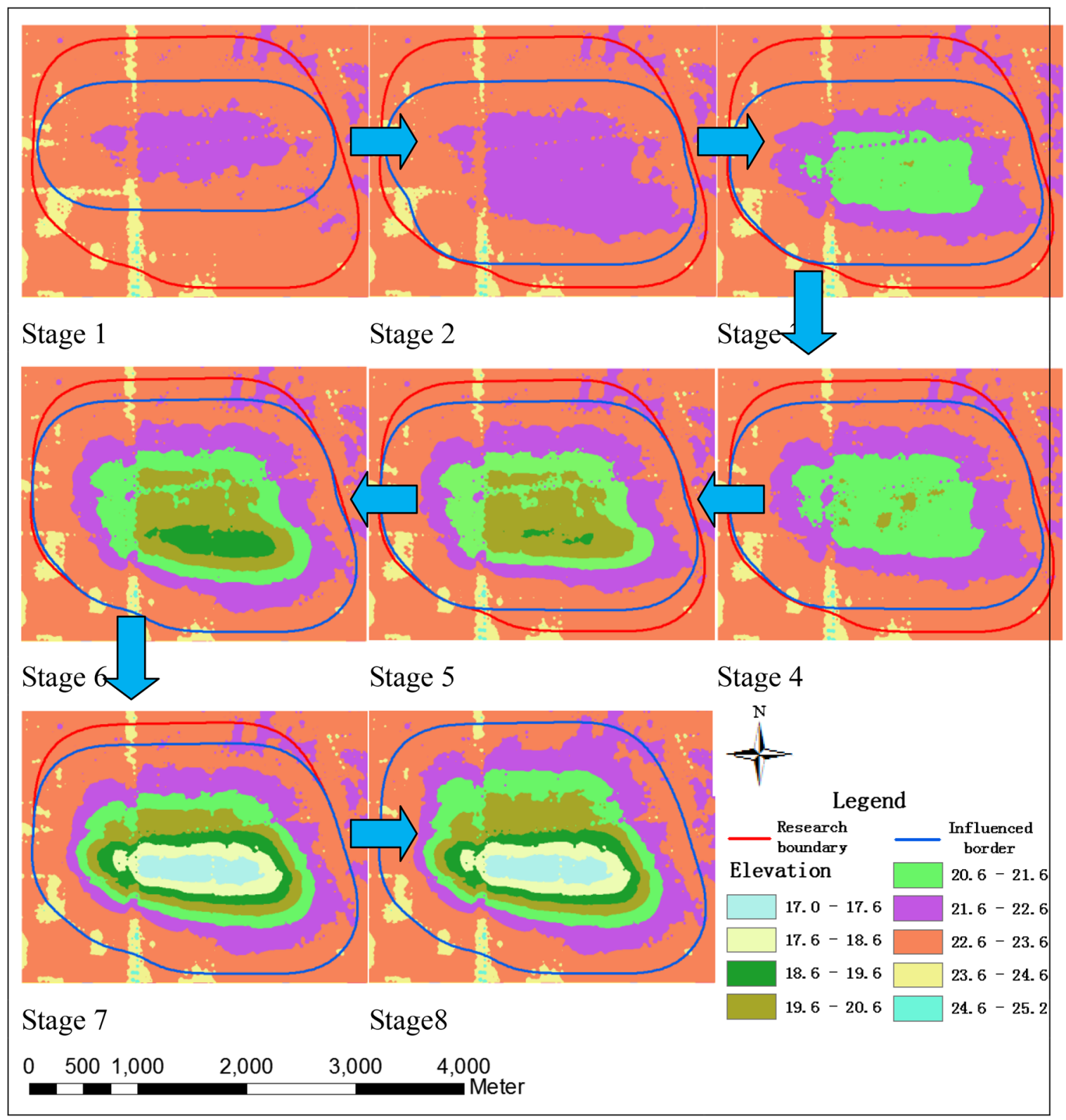

Fig. 7 Surface topography after each mining stage—Case study I

The P5 is located above P2 and after its extraction, subsidence impact areas related to these two panels are superimposed and the maximum subsidence increases significantly to $3302 \mathrm{~mm}$; Stage 6: P6 is adjacent to P2, and the subsidence-influenced region and water-logged areas increase gradually and extend to the south side; Stage 7: P7 is mined above P3 and therefore maximum subsidence increases significantly to a value of $5779 \mathrm{~mm}$. Since P4 is the last panel on the south side, the subsidence impacts reach their final boundary on the south side; Stage 8: The subsidence-influence region and water-logged areas further expand towards north side due to P8 and one big pond appears around the center of the TR study area.

\subsubsection{Comparison of $T R$ and CMR reclamation plans}

(1) TR plan All reclamation is planned during the ninth year after P8 mining. The regions which submerge under water would be dug deeper to get about 0.66 million $\mathrm{m}^{3}$ of soil. The areas adjacent to the edges of the influence area will be graded as farmland and another 0.89 million $\mathrm{m}^{3}$ of soil will be obtained and used as fill material. The average elevation of the original topography $\left(H_{0}\right)$ is $+23.1 \mathrm{~m}$, whereas the designed elevation of reclaimed farmland $\left(H_{\mathrm{R}}\right)$ is $+22.6 \mathrm{~m}$. So some soil will be obtained from the edge of basin where the elevation is more than 


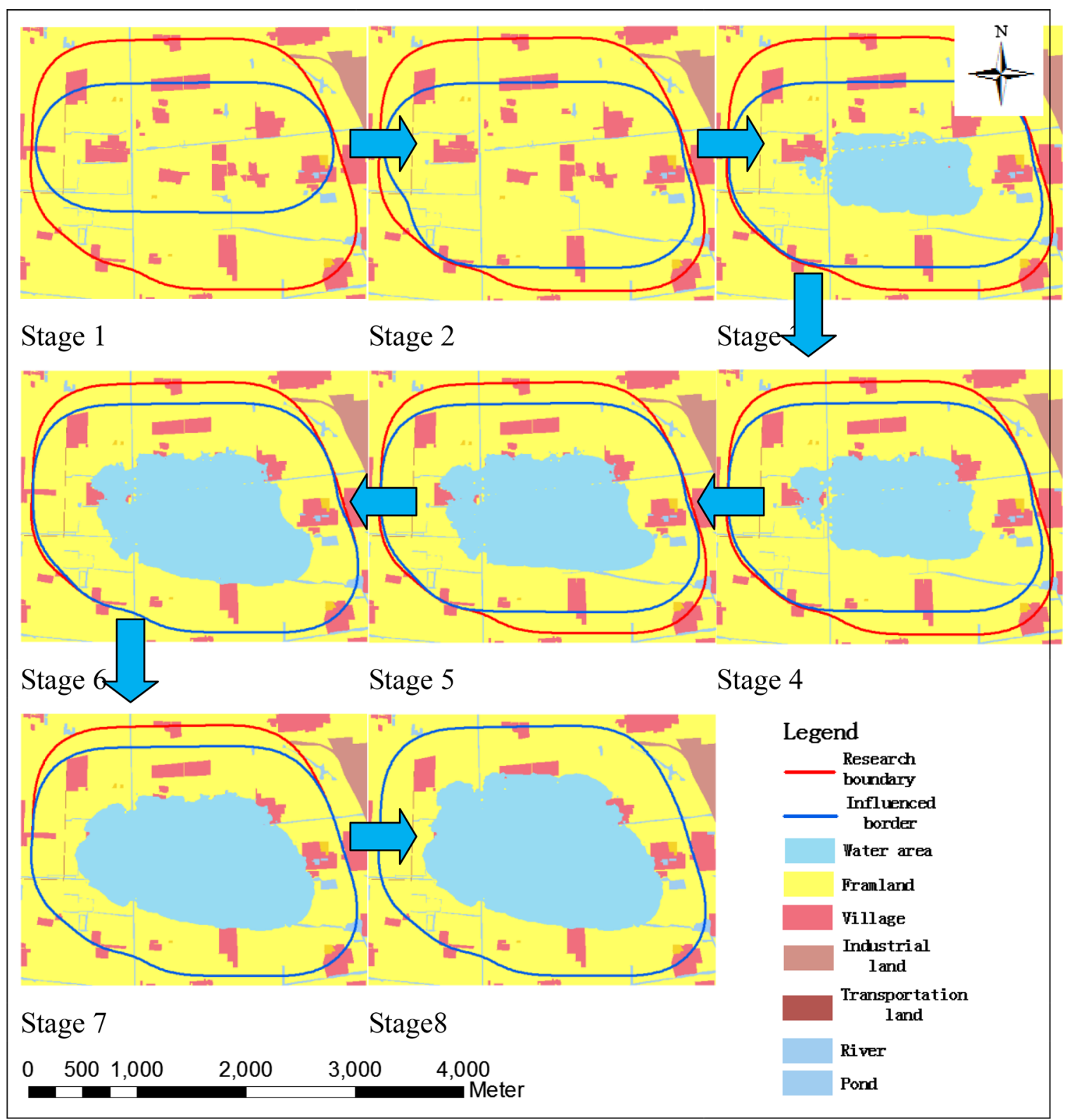

Fig. 8 Land use after each mining stage-Case study I

$+22.6 \mathrm{~m}$ after subsidence (Fig. 9). The dug-out soil will be used to fill low lying areas to the design elevation value of $+22.6 \mathrm{~m}$ to grow crops. One large pond will be constructed around the farmland (Fig. 10). Overall, the reclaimed study area will have 399.19 ha of farmland and 177.27 ha of water pond. Thus, it will result in cultivating about $69.25 \%$ of the case study area for farmland in the future (Table 3).

(2) CMR plan Several guiding principles were used to develop the CMR plans. These included: (1) local geographical environment, pre-mining land use patterns, and social and economic needs, (2) minimize cost to excavate and transport the soils, (3) dig deep, if necessary, to fill the shallow land areas to protect and enhance farmland, (4) grade the disturbed land as soon as possible and develop contour ditches to protect farmland and enhance farm productivity; (5) balance cutting and filling to minimize need for additional soil; (6) consider future subsidence of reclaimed land; and (7) maximize farmland and water resources protection and productivity of agriculture. Since farmland and rivers and ponds protection were the primary goals here, it was decided that the surface elevation of the final reclaimed farmland elevation should not be less 


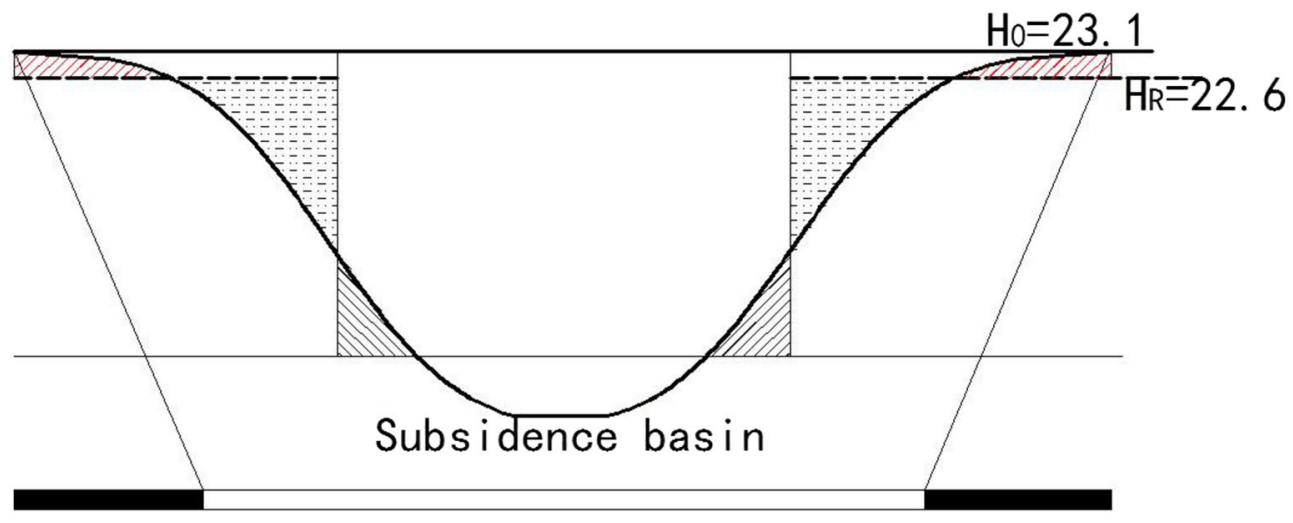

Filling area

Digging area

Fig. 9 Schematic diagram of filling and digging areas

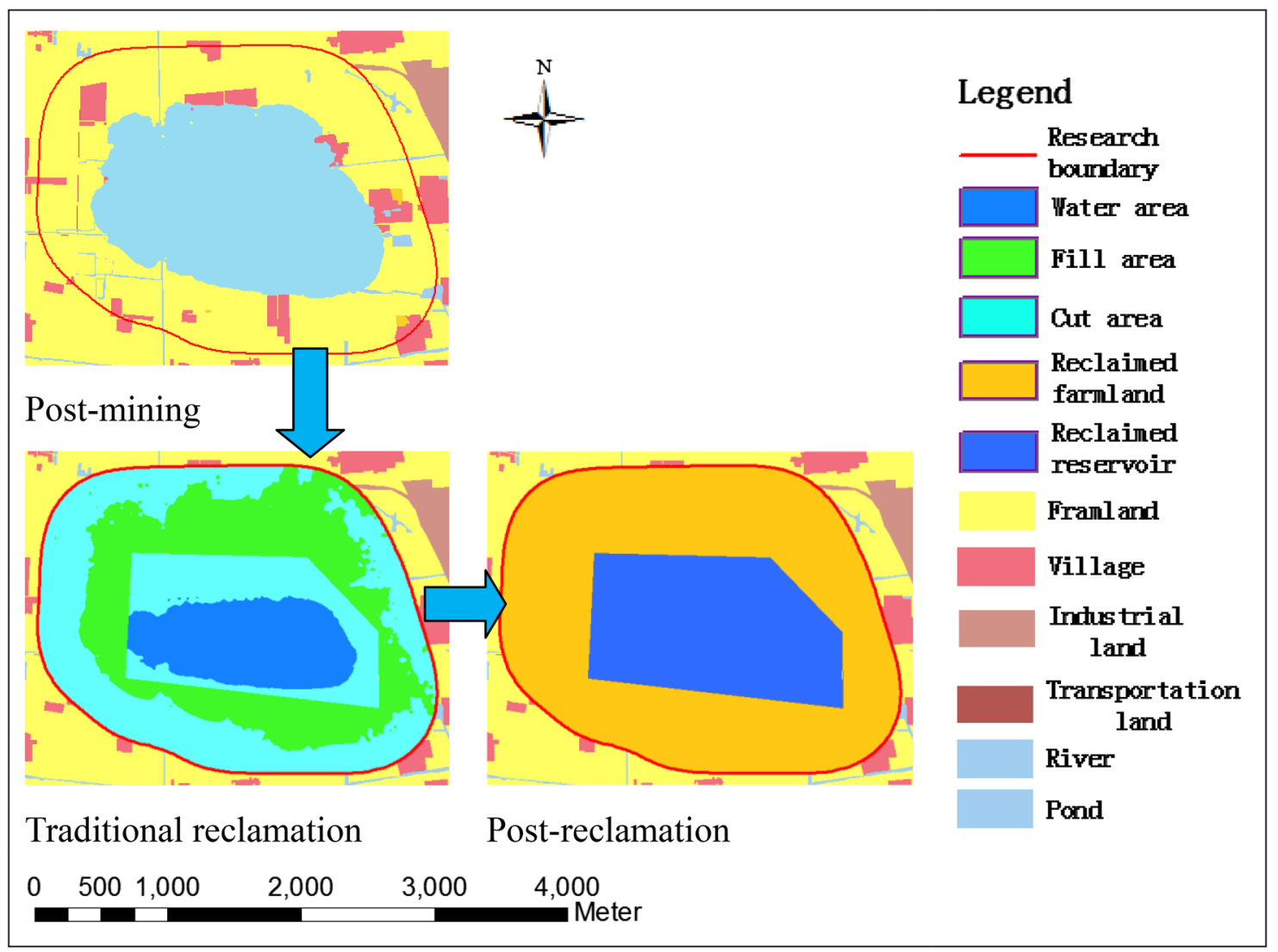

Fig. 10 TR plan reclamation layout—Case study I

than $+22.6 \mathrm{~m}$ The CMR activities for each phase are described below and are shown in Fig. 11.

Stage 1: Only a small part of the land is disturbed by mining subsidence and there are no water-logged areas; Stage 2: After mining P3, large area of land will submerge into water and therefore reclamation in advance is necessary. It is proposed to dig about 0.96 million $\mathrm{m}^{3}$ of soil dug from the deep region above P2 to form a small reservoir. With expected future subsidence, the dug-out soil is used as filling material to raise the elevation of the surrounding regions in south and west sides so that land can be used as farmland; Stage 3: In order to save the precious soil, reservoir will be extended towards the P3 direction, and about 0.84 million $\mathrm{m}^{3}$ of soil will be dug-out to fill the 
Table 3 Relevant reclamation data for TR plan- Case study I

\begin{tabular}{lllll}
\hline Plan & $\begin{array}{l}\text { Farmland } \\
\text { (ha) }\end{array}$ & $\begin{array}{l}\text { Water } \\
\text { area(ha) }\end{array}$ & $\begin{array}{l}\text { Water } \\
\text { volume } \\
\left(\text { million } \mathrm{m}^{3}\right)\end{array}$ & $\begin{array}{l}\text { Earthwork } \\
(\text { million } \\
\left.\mathrm{m}^{3}\right)\end{array}$ \\
\hline TR & 399.19 & 177.27 & 4.78 & 1.55 \\
CMR & 477.48 & 98.98 & 5.56 & 3.36 \\
\hline
\end{tabular}

northeast area which is otherwise expected to be waterlogged due to mining subsidence.

Stage 4: With the extraction of P4, the region above P4 would submerge under water. So the reservoir will be further enlarged to the north side to obtain 0.38 million $\mathrm{m}^{3}$ of filling soil and the shallow region in the northwest side is reclaimed as farmland; Stage 5: The reservoir is projected to reach its final boundary. About 0.29 million $\mathrm{m}^{3}$ of soil will be dug-out from the reservoir to fill the east side region, and contour ditches are constructed to help transport water to the reservoir; Stage 6: Around the western edge of the final subsidence-influenced area, land will be regraded for farmland. About 0.30 million $\mathrm{m}^{3}$ of soil will be obtained from the region where surface elevation exceeds $+22.6 \mathrm{~m}$ after subsidence, and the shallow areas around it will be filled to above $+22.6 \mathrm{~m}$ level to cultivate crops; Stage 7: Due to the original surface topography and mining subsidence, only 0.29 million $\mathrm{m}^{3}$ of soil can be

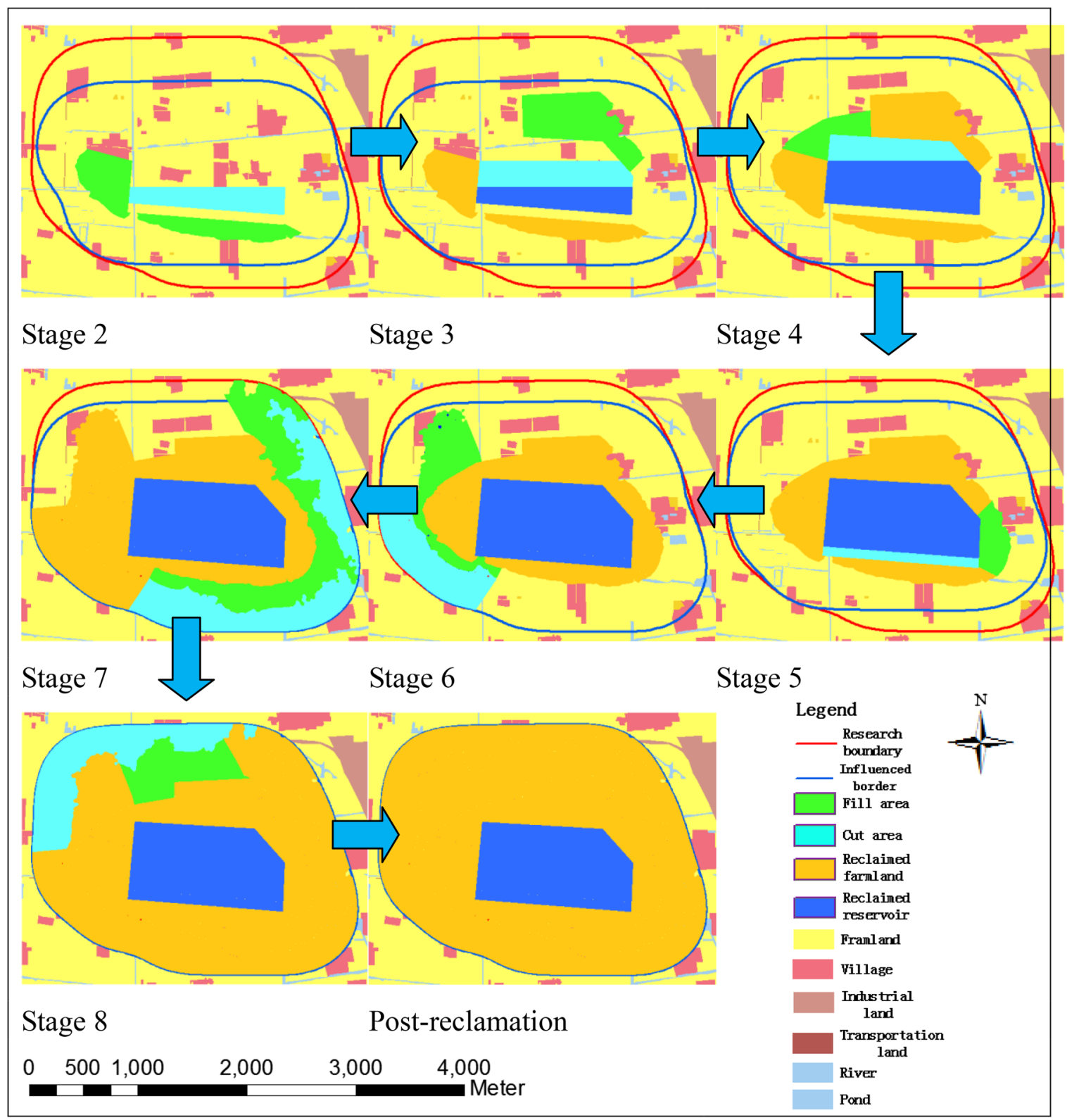

Fig. 11 CMR plan reclamation layout-Case study I 
Table 4 Reclaimed farmland and water reservoir areas during different mining stages - Case study I

\begin{tabular}{llllll}
\hline Stage & \multicolumn{2}{l}{ Farmland } & & \multicolumn{2}{l}{ Water reservoir } \\
\cline { 2 - 3 } \cline { 5 - 6 } \cline { 5 - 6 } & Area (ha) & Percentage (\%) & & Area (ha) & Percentage (\%) \\
\hline 1 & 500.33 & 86.79 & 0.00 & 0.00 \\
2 & 476.10 & 82.59 & & 29.23 & 5.07 \\
3 & 471.99 & 81.88 & 62.23 & 10.80 \\
4 & 452.65 & 78.52 & 86.57 & 15.02 \\
5 & 445.24 & 77.24 & 98.98 & 17.17 \\
6 & 450.24 & 78.10 & 98.98 & 17.17 \\
7 & 463.24 & 80.36 & 98.98 & 17.17 \\
8 & 477.48 & 82.83 & 98.98 & 17.17 \\
\hline
\end{tabular}

Table 5 Available farmland for cultivation for TR and CMR plansCase study I

\begin{tabular}{|c|c|c|c|c|c|}
\hline \multirow[t]{2}{*}{ Year } & \multicolumn{2}{|c|}{ TR plan } & \multicolumn{2}{|c|}{ CMR plan } & \multirow{2}{*}{$\begin{array}{l}\text { Difference (\%) } \\
\text { (TR-CMR) }\end{array}$} \\
\hline & $\begin{array}{l}\text { Area } \\
\text { (ha) }\end{array}$ & $\begin{array}{l}\% \text { of } \\
\text { total }\end{array}$ & $\begin{array}{l}\text { Area } \\
\text { (ha) }\end{array}$ & $\begin{array}{l}\% \text { of } \\
\text { total }\end{array}$ & \\
\hline 1 & 500.33 & 86.79 & 500.33 & 86.79 & 0.00 \\
\hline 2 & 500.33 & 86.79 & 476.10 & 82.59 & 4.20 \\
\hline 3 & 420.06 & 72.87 & 471.99 & 81.88 & -9.01 \\
\hline 4 & 389.84 & 67.63 & 452.65 & 78.52 & -10.90 \\
\hline 5 & 356.71 & 61.88 & 445.24 & 77.24 & -15.36 \\
\hline 6 & 341.54 & 59.25 & 450.24 & 78.10 & -18.86 \\
\hline 7 & 320.97 & 55.68 & 463.24 & 80.36 & -24.68 \\
\hline 8 & 292.84 & 50.80 & 477.48 & 82.83 & -32.03 \\
\hline $\begin{array}{l}9 \text { (after } \\
\quad \text { reclamation) }\end{array}$ & 399.19 & 69.25 & 477.48 & 82.83 & -13.58 \\
\hline
\end{tabular}

obtained from the large region in the south and east of the subsidence basin, and is used to fill the area adjacent to it; Stage 8: The last panel on the north side is proposed to be mined, and 0.30 million $\mathrm{m}^{3}$ of soil would be obtained from the relatively high areas to fill the shallow areas to be cultivated as farmland. The large reservoir is proposed to be developed as a Water Park to improve eco-environment and local economy. It will also provide water resources for farmland irrigation and local area industries at the same time. The resulting reservoir area and cultivated farmland cultivated in each mining stage based on the developed CMR plan is shown in Table 4 with the estimate that about there would be 477.48 ha will be reclaimed as farmland which accounts for $82.83 \%$ of the total study area.

\subsubsection{Comparison of TR and CMR plans}

(1) Farmland utilization The percentages of farmland in TR plan are $50.80 \%$ to $72.87 \%$ lower than that in the CMR plan during years 3-9. Even upon completion of all reclamation activities the percent reclaimed farmland in TR is about $69.25 \%$ as compared to $82.83 \%$ in the CMR Plan (Table 5).

(2) Water resources development The data for the two plans is shown in Table 6. The area in TR is larger than in the CMR plan except for Years 1 and 2. However, the water volumes in TR plan are smaller than in the CMR plan since steps were taken to protect water resources as mining progressed to use them efficiently in future.

This case study has used all design and guiding principles discussed earlier to demonstrate that CMR plans have both short-term and long-term benefits for sustainable mining, with farmland use and protection and regional economic development. It represents analysis of only one CMR plan which may not be optimum. Alternate CMR plans could be developed that provide even more benefits than this one.

Table 6 Water resources areas and volumes in TR and CMR plans-Case study I

\begin{tabular}{|c|c|c|c|c|c|c|}
\hline \multirow[t]{2}{*}{ Year } & \multicolumn{2}{|l|}{ TR plan } & \multicolumn{2}{|l|}{ CMR plan } & \multicolumn{2}{|c|}{ Difference (TR-CMR) } \\
\hline & Area (ha) & Volume (million $\mathrm{m}^{3}$ ) & Area (ha) & Volume (million $\mathrm{m}^{3}$ ) & Area (ha) & Volume (million $\mathrm{m}^{3}$ ) \\
\hline 1 & 0.00 & 0.00 & 0.00 & 0.00 & 0.00 & 0.00 \\
\hline 2 & 0.00 & 0.00 & 29.23 & 0.58 & -29.23 & -0.58 \\
\hline 3 & 90.27 & 0.47 & 62.23 & 2.15 & 28.04 & -1.68 \\
\hline 4 & 125.49 & 0.74 & 86.57 & 2.74 & 38.92 & -2.00 \\
\hline 5 & 163.62 & 1.57 & 98.98 & 3.72 & 64.64 & -2.15 \\
\hline 6 & 183.79 & 1.98 & 98.98 & 3.97 & 84.81 & -1.99 \\
\hline 7 & 209.36 & 4.18 & 98.98 & 5.55 & 110.38 & -1.36 \\
\hline 8 & 242.49 & 4.51 & 98.98 & 5.56 & 143.52 & -1.05 \\
\hline 9 (after reclamation) & 177.27 & 4.78 & 98.98 & 5.56 & 78.30 & -0.78 \\
\hline
\end{tabular}




\subsection{Case study II (Shandong Province, years 2009-2014)}

This case study was recently published by $\mathrm{Hu}$ et al. (2016b) and represents the state-of-the-art in CMR planning techniques. It is included here only in a summary form to strengthen some of the principles discussed in earlier sections.

\subsubsection{Description of the case study area}

The study area (Fig. 12) is located in southwest of Shandong Province with relatively high GWL of $2.5 \mathrm{~m}$. The highly productive farmland area covers about $86.60 \%$ of the entire mining area (Fig. 13). Corn and wheat are the most important crops and the multiple cropping index is $200 \%$.

\subsubsection{Geology and mining plan}

No. 3 coal seam, $9 \mathrm{~m}$ thick is mined in the study area and the seam pitches average of $5^{\circ}$ (Hu et al. 2016b). Relevant subsidence prediction parameters are given in Table 1. There are five (5) longwall mining panels (Fig. 14) in the area with the mining sequence of P1-P2-P3-P4-P5, and average face advance rate of $5 \mathrm{~m}$ per day.

\subsubsection{Subsidence impacts analysis}

Similar to case study I, mining of the area was divided into five (5) phases based on the mining layout: Phase 1completion of face $\mathrm{P} 1$; Phase 2-completion of faces P1and P2; Phase 3-completion of faces P1, P2 and P3; Phase 4-completion of faces P1, P2, P3 and P4; and Phase 5-completion of faces P1, P2, P3, P4 and P5. In the end about $36.57 \%$ of the land would submerges under water and cannot be used for farming (Table 7).

\subsubsection{Comparison of CMR and traditional reclamation (TR) plans}

Similar to in Case study I, farmland availability with TR (Fig. 15) and CMR (Fig. 16) plans are summarized in Table 8. The differences in each phase vary from 3.01 to $37.14 \%$. Upon completion, the reclaimed farmland by CMR is higher $(88.5 \%)$ with long-term revenue benefits as compared to TR $(75.56 \%)$.

Water resource volume data during mining (Years 1-5) and after TR completion (Year 6) are shown in Table 9. The available water resources volumes with CMR are much higher than TR. Final water volume by CMR is 8.80 million $\mathrm{m}^{3}$, which is $15.01 \%$ more than TR. CMR planning measures can protect water resources in the subsided areas through stripping topsoil before it sinks into water and is

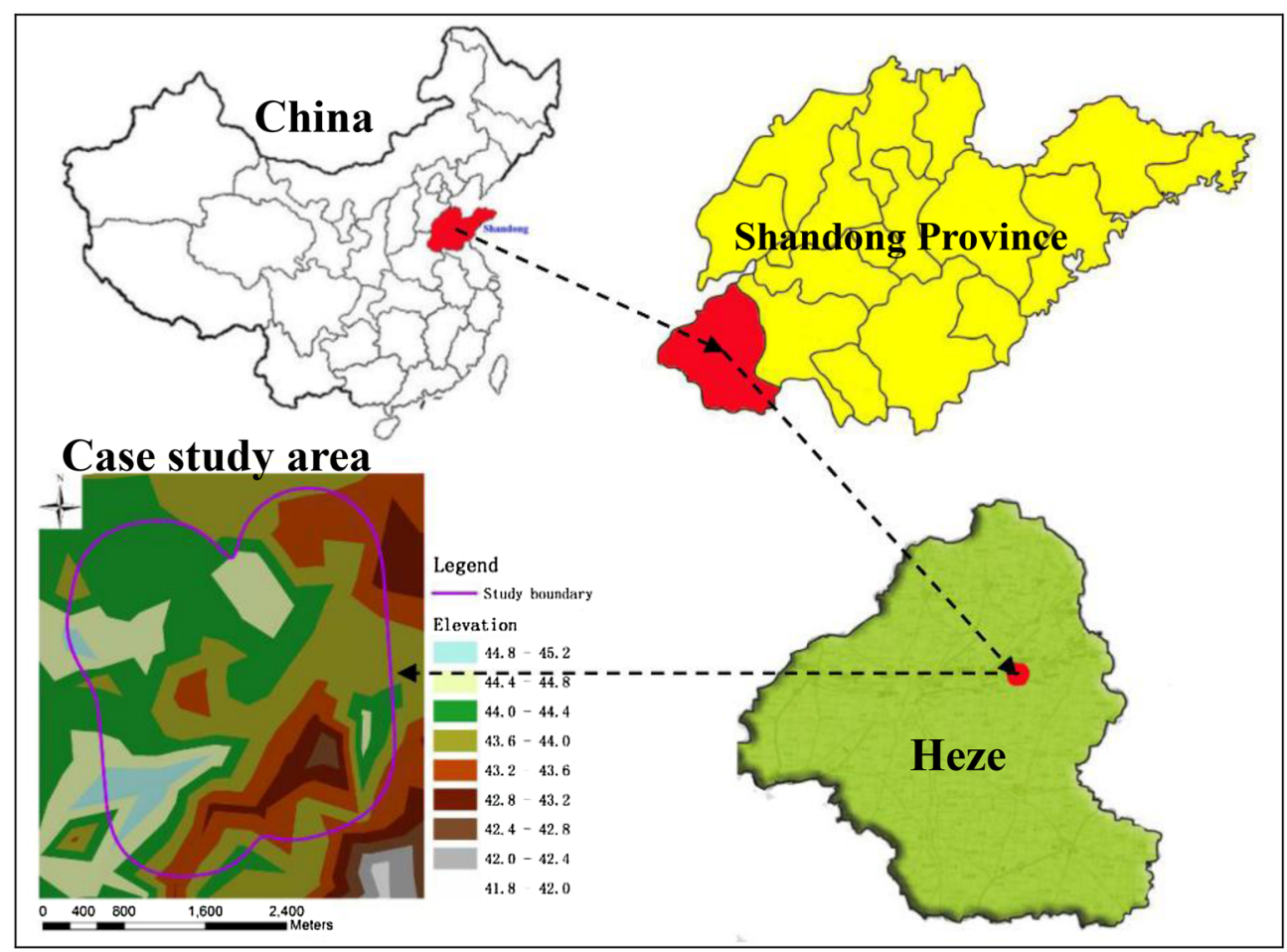

Fig. 12 Location and pre-mining surface topography of Case study II 


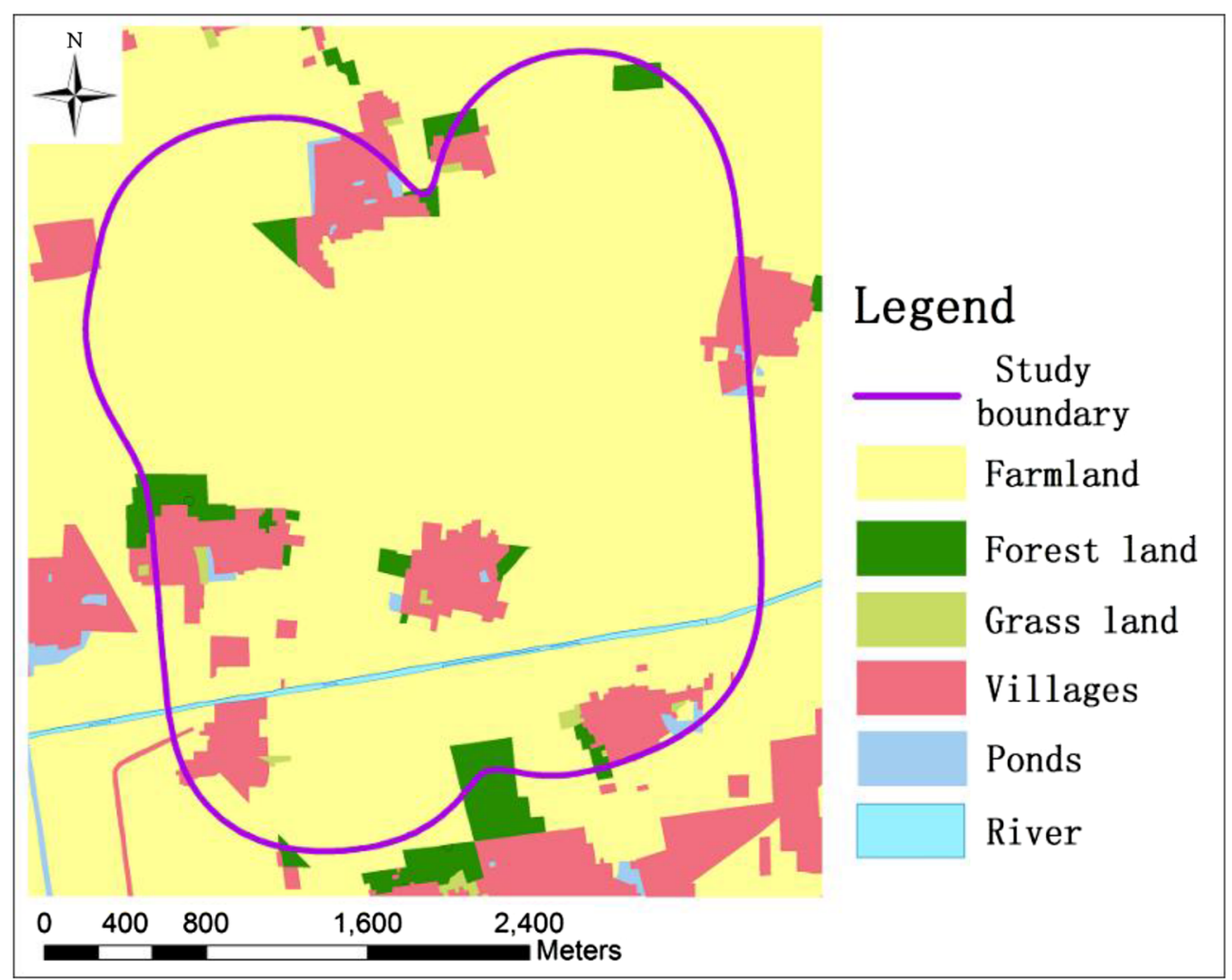

Fig. 13 Pre-mining land use distribution-Case study II

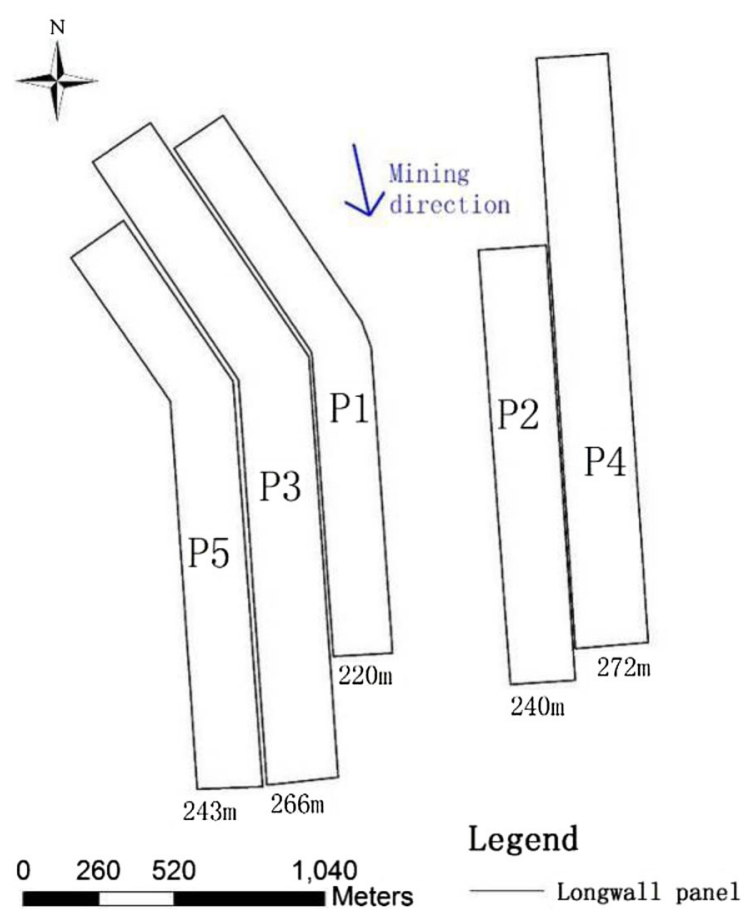

Fig. 14 Layout of longwall panels-Case study II

used as filling material in low-lying areas. Soil erosion is controlled and water resources are channeled into reservoirs where they can be used in future. Water storage areas
Table 7 Subsidence influence area, water area and farmland in each mining phase -Case study II

\begin{tabular}{|c|c|c|c|c|c|}
\hline & \multirow{2}{*}{$\begin{array}{l}\text { Influence } \\
\text { area (ha) }\end{array}$} & \multicolumn{2}{|c|}{ Water area } & \multicolumn{2}{|c|}{ Farmland } \\
\hline & & $\begin{array}{l}\text { Area } \\
\text { (ha) }\end{array}$ & $\begin{array}{l}\text { Proportion } \\
\text { (\%) }\end{array}$ & $\begin{array}{l}\text { Area } \\
\text { (ha) }\end{array}$ & $\begin{array}{l}\text { Proportion } \\
\text { (\%) }\end{array}$ \\
\hline $\begin{array}{c}\text { Phase } \\
1\end{array}$ & 355.04 & 44.40 & 4.88 & 749.39 & 82.32 \\
\hline $\begin{array}{c}\text { Phase } \\
2\end{array}$ & 549.42 & 102.28 & 11.24 & 692.49 & 76.07 \\
\hline $\begin{array}{c}\text { Phase } \\
3\end{array}$ & 721.53 & 197.16 & 21.66 & 598.81 & 65.78 \\
\hline $\begin{array}{c}\text { Phase } \\
4\end{array}$ & 846.07 & 278.74 & 30.62 & 517.65 & 56.87 \\
\hline $\begin{array}{c}\text { Phase } \\
5\end{array}$ & 910.31 & 332.93 & 36.57 & 467.58 & 51.36 \\
\hline
\end{tabular}

can be effectively used as fish ponds with good water management. It can also be used to design as water or wet land park which should benefit the local people and ecoenvironment. 


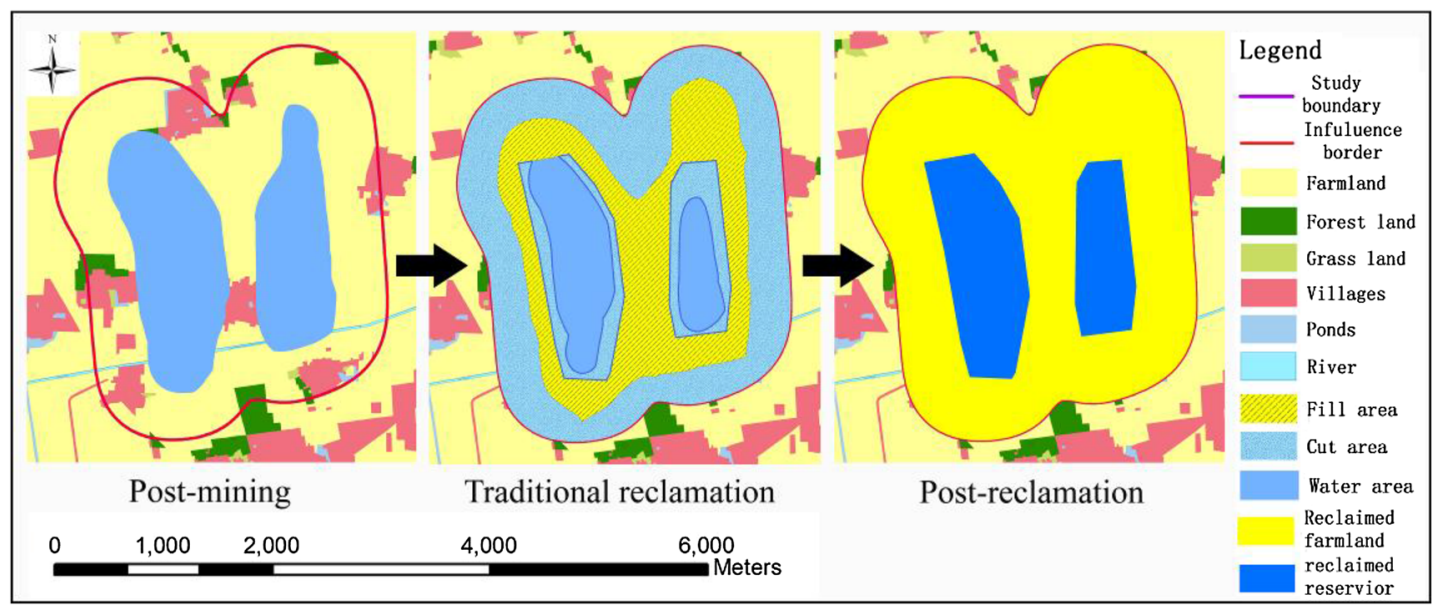

Fig. 15 Traditional reclamation (TR) plan-Case study II

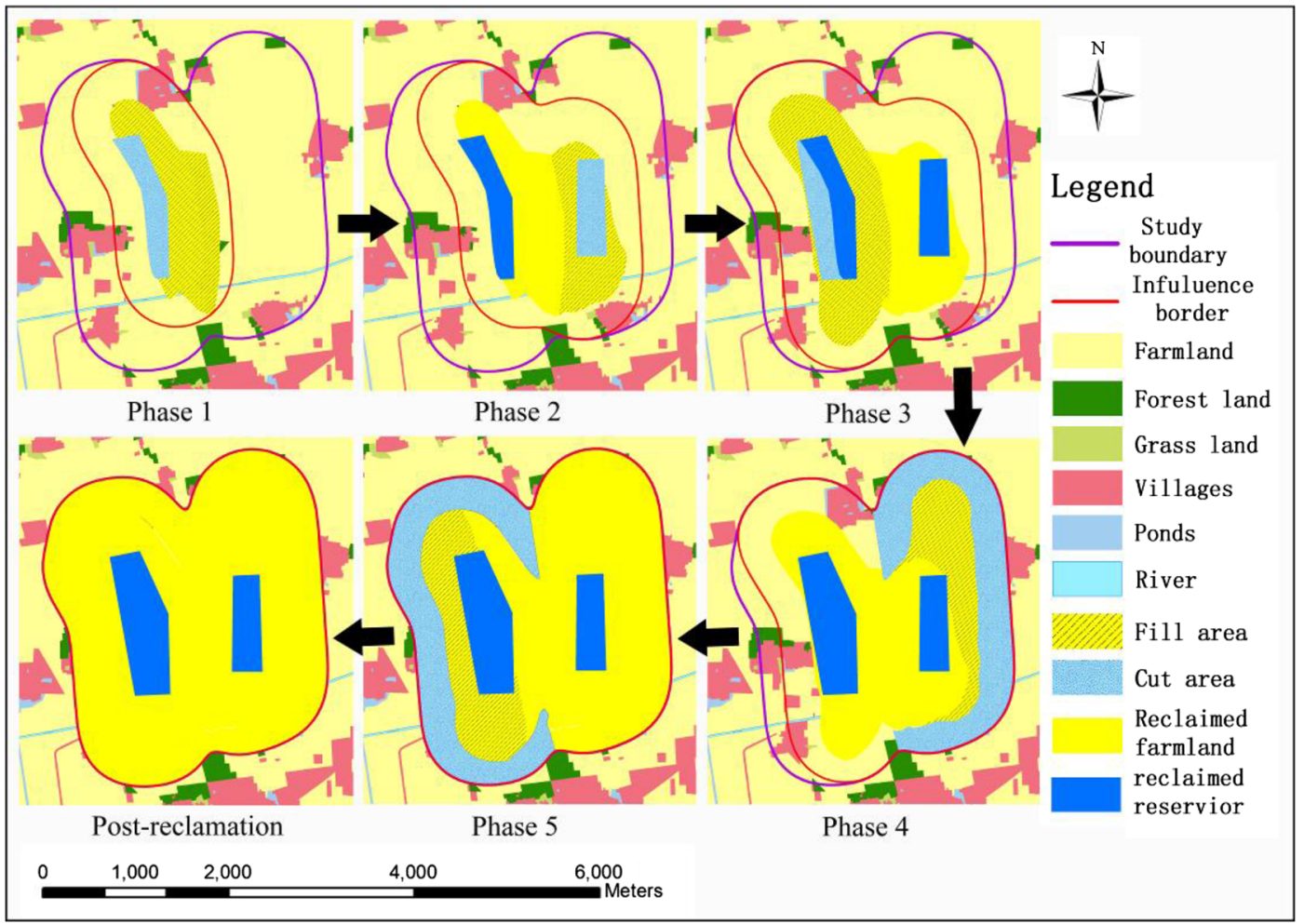

Fig. 16 CMR plans during different mining phases-Case study II

\section{Underground mining and reclamation practices for prime agricultural lands in Illinois, USA}

\subsection{Industry overview}

Over $70 \%$ of the State of Illinois is underlain by coal with the worlds' largest bituminous coal reserve base (about 85 billion tons of demonstrated reserves). In 2014 Illinois produced about 58 million $\mathrm{mt}$ of coal employing 4100 persons. About $90 \%$ of coal was mined using underground mining methods, and about $80 \%$ of it using retreat longwall mining methods. The average productivity for all underground mines was $7.35 \mathrm{mt}$ per hour while productivity from longwall mines ranged 10-12 $\mathrm{mt}$ per hour (Illinois Office of Mines and Minerals Annual Report 2015).

\subsection{Geology and mine characteristics}

Almost all the coal was mined from two coal seams (No. 6 or Herrin, and No. 5 or Harrisburg). They vary in thickness 
Table 8 Farmland utilization in TR plan and CMR plans-Case study II

\begin{tabular}{lllllll}
\hline Year & \multicolumn{2}{l}{ TR plan } & & \multicolumn{2}{l}{ CMR plan } & $\begin{array}{l}\text { Difference (\%) } \\
\text { (TR-CMR) }\end{array}$ \\
\cline { 2 - 3 } $\begin{array}{l}\text { Area } \\
\text { (ha) }\end{array}$ & $\begin{array}{l}\text { Proportion } \\
(\%)\end{array}$ & & $\begin{array}{l}\text { Area } \\
\text { (ha) }\end{array}$ & $\begin{array}{l}\text { Proportion } \\
(\%)\end{array}$ & \\
\hline 1 & 749.39 & 82.32 & & 776.74 & 85.33 & -3.01 \\
2 & 692.49 & 76.07 & & 759.12 & 83.39 & -7.32 \\
3 & 598.81 & 65.78 & & 735.57 & 80.80 & -15.02 \\
4 & 517.65 & 56.87 & & 771.37 & 84.74 & -27.87 \\
5 & 467.58 & 51.36 & 805.62 & 88.50 & -37.13 \\
6 & 687.83 & 75.56 & 805.62 & 88.50 & -12.94 \\
\hline
\end{tabular}

Table 9 Comparison of water resources in TR plan and CMR planCase study II

\begin{tabular}{|c|c|c|c|c|c|}
\hline \multirow[t]{2}{*}{ Year } & \multicolumn{2}{|c|}{ TR plan } & \multicolumn{2}{|c|}{ CMR plan } & \multirow{2}{*}{$\begin{array}{l}\text { Difference } \\
\left(\text { million } \mathrm{m}^{3}\right) \\
(\mathrm{TR}-\mathrm{CMR})\end{array}$} \\
\hline & $\begin{array}{l}\text { Area } \\
\text { (ha) }\end{array}$ & $\begin{array}{l}\text { Volume } \\
\text { (million } \\
\left.\mathrm{m}^{3}\right)\end{array}$ & $\begin{array}{l}\text { Area } \\
\text { (ha) }\end{array}$ & $\begin{array}{l}\text { Volume } \\
\text { (million } \\
\mathrm{m}^{3} \text { ) }\end{array}$ & \\
\hline 1 & 44.40 & 0.22 & 39.85 & 1.81 & -1.60 \\
\hline 2 & 102.28 & 0.68 & 73.96 & 3.44 & -2.77 \\
\hline 3 & 197.16 & 3.03 & 104.69 & 6.61 & -3.59 \\
\hline 4 & 278.74 & 4.95 & 104.69 & 7.57 & -2.63 \\
\hline 5 & 332.93 & 7.04 & 104.69 & 8.80 & -1.77 \\
\hline 6 & 222.48 & 7.66 & 104.69 & 8.80 & -1.15 \\
\hline
\end{tabular}

from 1.3 to $2.1 \mathrm{~m}$ and are mined at depths varying 36-270 $\mathrm{m}$. The seven longwall faces operate at depths varying from 120 to $220 \mathrm{~m}$. The coal seams are overlain by weak shales, sandstones, and limestones (20-60 MPa uniaxial compressive strength or UCS), and underlain by weak claystone and shales (5-15 MPa UCS). Caving of roof strata typically occurs immediately behind the face shield supports.

\subsection{Regional surface and climate characteristics}

Most of the coal in Illinois is mined in southern Illinois. The surface topography in the region is flat to gently rolling with surface slopes of less than 5\% but with local slopes reaching $10-15 \%$. Illinois also is blessed with some of richest quality farmland in the world termed "Prime Farmland". Corn and soybeans are the primary crops that grow on poorly-drained soils (Darmody et al. 2014). Temperatures from April to August range $15-25^{\circ} \mathrm{C}$ and about $80-120 \mathrm{~mm}$ of rainfall occurs during the above period.

\subsection{Mining operations and subsidence characteristics}

All the seven longwall face operate super-critical faces with width varying from 300 to $360 \mathrm{~m}$; with some faces proposed to be $450 \mathrm{~m}$ wide. The face lengths vary 4500-9000 m. Three-entry development entries are practiced with the width of the development entry pillar system varying from 70 to $100 \mathrm{~m}$ depending upon seam underlying floor characteristics. The face advance rate ranges $27-36 \mathrm{~m}$ per day. Thus typical mining life for a panel ranges $0.5-1.0$ years. The angle of draw and subsidence factor values within the subsidence basin typically vary $15^{\circ}-25^{\circ}$, and $0.55-0.7$, respectively. Maximum subsidence values around the center of the panel range 1.2-1.8 $\mathrm{m}$. The chain pillars of development entries typically subside about $300 \mathrm{~mm}$. About $80 \%$ of the maximum subsidence occurs behind the face after the longwall face has advanced about $100 \mathrm{~m}$, with the remaining residual subsidence occurring within 3-4 months after mining.

\subsection{Subsidence impacts analysis}

With above discussion of surface and mining characteristics, subsidence impacts typically include: (1) shallow water-logged areas, (2) changes in drainage around the edges of subsidence basin, (3) breaking of drain-tiles around the edges of the subsidence basin where tensile and compressive strains can be high, (4) short-term flow changes in perennial and intermittent streams, (5) damage to temporary and permanent structures, submergence of topsoil and subsoil in water if it is not removed in a timely fashion; and damage to infra-structures (roads, culverts, bridges, etc.). Since land is privately controlled, or owned by organizations (parks, forests, etc.) the coal company must interface with individual land owners and organizations to deal with subsidence impacts.

\subsection{Subsidence reclamation regulations}

Farmland mitigation requirements are given in Section 1817.121 (Subsidence Control) of the 62 Ill. Adm. Code 1817.121(c) (1), and are effective June 27, 2005. These are written to protect the land and water resources overlying the underground-mined areas. It requires that the mining company must have an approved reclamation plan prior to issuance of mining permit. The philosophy behind subsidence reclamation requirements was best summarized by Barkley (2017). Surface mining of prime agricultural lands requires classifying the pre-mining farmland into low capability, high capability, and prime based on productivity. Prior to issuance of mining permit, the coal company must post a reclamation bond which will be released only 
after the company has demonstrated the post mining yields to be equal to or greater than pre-mining yield capability. The State of Illinois is the only state in the USA that requires low and high capability designations.

Surface impacted areas due to underground mining however do not require to sub-classify the land similar to above and there are no yield-based performance requirements for reclaimed subsided lands. The primary goal of subsidence reclamation is to ensure appropriate drainage since agricultural soils drain poorly and shallow waterlogged areas are likely to develop. The permitting agency hypothesizes that with drainage restoration the land should have similar yields as before subsidence. This hypothesis was developed based on extensive studies performed by Illinois researchers (Darmody et al. 2014) under the Illinois Mine Subsidence Research Program over a period of ten rears (1985-1995). The results showed that subsidence impacts on agricultural productivity are small as long as drainage is maintained. It also considers that farmland productivity depends upon how farming is done.

\section{Concurrent mining and reclamation of subsidence impacts in China and in Illinois, USA: some thoughts}

CMR is a complex planning tool that can enhance the value of land and water resources reclamation as demonstrated through multiple case studies included and referred to in this paper. However, it requires significant cooperation among land owners, water resources companies, and regional economic development agencies. Therefore, it can be commercially applied in countries which have more centralized control. It is an excellent technology that can make mining more sustainable with both short-term and long-term benefits. Some of the prerequisites for its success are not present in the USA. For example, mining alternate panels far away from each other, or mining alternate panels in multiple seams is not common. Similarly, the face advance rates are 10-20 times higher than in China. So, dynamic reclamation planning becomes an extremely important unit operation that can negatively impact operations productivity. Mining companies may not want to risk negative impact to mining operations. The maximum subsidence is much smaller than in China that can be easily mitigated through relatively easy regrading activities. Furthermore, since mining companies are operating supercritical panels, the areas around the panels experiencing higher ground slopes are a small percentage of the minedout panel area, the regrading efforts to ensure proper drainage for farmland cultivation are generally small and can be easily managed by high capacity equipment during the summer months when the soils are dry. Further development of CMR and its application should continue to make mining more sustainable in areas where there are competing interests between population, land use, and water resources use.

\section{Areas for further development of CMR}

The development of CMR was motivated by maximum utilization of farmland resources during the period when recovering valuable coal resources. However, as its development has gown and it is better understood, it could be used to minimize loss of or enhance any variable that would minimize subsidence impacts and improve regional economic and community development. Furthermore, it could consider multiple variables during the optimization process using principles of operations research and systems analysis. For example, protection of water, forest, land structures, or other critical resources could be interest variables. For this development, one would need good relative data on cost of associated reclamation and resulting revenue or economic enhancement for each variable considered. Such data are currently not available and should be developed. This area of development may also include order of extraction of multiple coal seams to maximize the objective function. Water resources, particularly potable water resources should be of immediate interest in China since the cost is very high. So, authors strongly recommend CMR development to protect and manage water resources in the near future. Synergizing CMR planning to protect multiple resources of national interest will require considerable cooperation among several agencies and may require central oversight and review. Further development of CMR should also include development of alternate, lower cost mining, backfilling, and reclamation technologies to take full advantage of CMR planning.

\section{Concluding remarks}

This paper provides an overview of the "Concurrent Mining and Reclamation or CMR" technology. CMR technology studies have demonstrated that farmland utilization and water resources development can be minimized and/or enhanced through CMR planning as compared to traditional reclamation approaches. It is an advanced technology in subsidence land reclamation, and a leading technology in the world. The application of CMR in China is explained in this paper through two case studies from different parts of China with different geologic conditions, surface topographic and hydrologic characteristics. Most of the CMR applications to date have focused to 
minimize the loss of farmland use for agriculture during and after the entire mining process without a consideration of regional economic planning. Case study II has attempted to quantify impacts of CMR planning on surface hydrologic resources. It has identified another important research area of CMR for minimization and/or enhancement of water resources quantity and quality related to underground mining of coal. Since water resources represent one of the global mega challenges, this area of research has very high potential. Furthermore, CMR planning studies require at a minimum sub-optimization studies, application of principles of systems analysis and operations research need to be incorporated. CMR planning has the potential to develop and sustain emerging economic communities while simultaneously recovering coal as a valuable energy resource. The concepts and technologies are scientifically sound with potential for applications around the global.

Additional CMR studies are currently in planning stages to document and reinforce the developed concepts here. The CMR planning will be facilitated through development of engineering and economic analyses software and is being considered. These tools will allow a better understanding of the effect of different CMR variables on development of concurrent mining and subsidence reclamation plans and their impact on cost effectiveness.

Open Access This article is distributed under the terms of the Creative Commons Attribution 4.0 International License (http://crea tivecommons.org/licenses/by/4.0/), which permits unrestricted use, distribution, and reproduction in any medium, provided you give appropriate credit to the original author(s) and the source, provide a link to the Creative Commons license, and indicate if changes were made.

\section{References}

Barkley D (2017) Private communication from March 1 to March 17, 2017

BP statistical reviews of world energy (2015). www.bp.com/ statisticalreview

Darmody RG, Bauer R, Barkley D, Clarke S, Hamilton D (2014) Agricultural impacts of longwall mine subsidence: the experience in Illinois, USA and Queensland, Australia. Int J Coal Sci Technol 1(2):207-212

Hu ZQ (1994a) A technique of reclaiming subsidence areas by use of a hydraulic dredge pump in Chinese coal mines. Int $\mathrm{J}$ Min Reclam Environ 8(4):137-140

Hu ZQ (1994b) Land reclamation plan for mining subsidence. Min Surv 2:32-34

Hu ZQ, Chen C (2016) Impact of underground coal mining on land ecology and its restoration in windy and sandy region. J Min Sci Technol 1(2):120-130

Hu ZQ, Luo YM (2006) Suggestions on environmental quality and food safety in overlapped areas of crop and mineral production. Sci Technol Rev 24(3):93-94

Hu ZQ, Xiao W (2013a) Optimization of concurrent mining and reclamation plans for single coal seam: a case study in Northern Anhui, China. Environ Earth Sci 68(5):1247-1254

Hu ZQ, Xiao W (2013b) New idea and new technology of mine land reclamation: concurrent mining and reclamation. Coal Sci Technol 41(9):178-181

Hu ZQ, Li J, Zhao YL (2006) Problems, reasons and countermeasures for environmental quality and food safety in the overlapped areas of crop and mineral production. Sci Technol Rev 24(3):21-24

$\mathrm{Hu}$ ZQ, Xiao W, Wang PJ, Zhang YL (2013) Concurrent mining and reclamation for underground coal mining. J China Coal Soc 38(2):301-307

$\mathrm{Hu}$ ZQ, Chen C, Xiao W et al (2016a) Surface movement and deformation characteristics due to high-intensive coal mining in the windy and sandy region. Int J Coal Sci Technol 3(3):339-348

$\mathrm{Hu}$ ZQ, Zhang RY, Chugh YP, Jia J (2016b) Mitigating mine subsidence dynamically to minimize impacts on farmland and water resources: a case study. Int J Environ Pollut 59(2):169-186

Illinois Office of Mines and Minerals Annual Report (2015). https:// www.dnr.illinois.gov/mines/Pages

Li TQ, Qi JZ, Zhou JH, Jiang S (1999) Method for pre-reclamation of dynamic subsidence area in Liuqiao No. 2 Coal Mine. Min Surv 2:57-58

Xiao W, Hu ZQ, Zhang RY, Zhao YL (2013) A simulation of mining subsidence and its impacts to land in high ground water area-an integrated approach based on subsidence prediction and GIS. Disaster Adv 6(S4):142-148

Xiao W, Hu ZQ, Fu YH (2014a) Zoning of land reclamation in coal mining area and new progresses for the past 10 years. Int J Coal Sci Technol 1(2):177-183

Xiao W, Hu ZQ, Chugh YP, Zhao YL (2014b) Dynamic subsidence simulation and topsoil removal strategy in high-groundwater table and underground coal mining area-a case study in Shandong Province. Int J Min Reclam Environ 28(4):250-263

Zhao YL, Hu ZQ (2008) Proper time model for pre-reclamation of unstable subsidence. J China Coal Soc 33(2):157-161 